\title{
Low frequency conduction block: a promising new technique to advance bioelectronic medicines
}

\author{
Silvia V. Conde ${ }^{1,2}$
}

\begin{abstract}
Nerve conduction block is an appealing way to selective target the nervous system for treating pathological conditions. Several modalities were described in the past, with the kilohertz frequency stimulation generating an enormous interest and tested successfully in clinical settings. Some shortcomings associated with different modalities of nerve blocking can limit its clinical use, as the "onset response", the high demand of energy supply, among others. A recent study by Muzquiz and colleagues describes the efficacy and reversibility of low frequency alternating currents in blocking the cervical vagus in the pig, in the absence of an onset effect and apparent lack of neuronal damage.
\end{abstract}

Keywords: low frequency alternating current, reversibility, efficacy, onset response, high frequency stimulation

Electrical stimulation of nerves has been used for years, experimentally and clinically, to modulate excitability of cells and neurocircuitries within the body. One of the modalities of electrical stimulation, for which there has been an enormous interest, is the high frequency stimulation, which uses electrical frequencies within the range of $1-50 \mathrm{kHz}$ to achieve reversible nerve conduction block(Patel et al. 2018). Seeking its clinical potential within the bioelectronic medicines field, kilohertz frequency stimulation to induce nerve conduction block was tested with success, in several peripheral nerves to tackle pathological conditions as obesity(Apovian et al. 2017; Sarr et al. 2012)and type 2 diabetes(Sacramento et al. 2018), to improve bladder function(Boger et al. 2008; Boger et al. 2012)and for modulation of chronic pain(Taylor et al. 2020; Youn et al. 2015). High frequency stimulation have several characteristics that makes it extremely attractive to be used as a nerve blocker as:

\footnotetext{
Correspondence: silvia.conde@nms.unl.pt

${ }^{1}$ iNOVA4Health, CEDOC, NOVA Medical School, NMS, Faculdade Ciências

Médicas, Universidade Nova de Lisboa, 1169-056 Lisboa, Portugal

${ }^{2}$ CEDOC, Centro Estudos Doenças Crónicas, NOVA Medical School, Faculdade de Ciências Médicas, Universidade Nova de Lisboa, Rua Câmara Pestana, nº, 6A, Edifício CEDOC II, piso 3, 1150-082 Lisboa, Portugal
}

(1) its reversibility in milliseconds(Sacramento et al. 2018; Kilgore et al. 2004; Fjordbakk et al. 2019); (2) its efficacy in large diameter nerves in large species (for a review see(Patel et al. 2018)) and in longterm(Sacramento et al. 2018); (3) the absence of neuronal damage(Sacramento et al. 2018; Ling et al. 2019)and (4) the possibility of providing partial nerve block(Patel et al. 2018; Bhadra et al. 2005). However, it exhibits some shortcomings that may hinder its clinical use. In this regard, kilohertz frequency stimulation has been associated to a transient hyperactivity of the nerve named "onset response"(Bhadra et al. 2005)that may bring unwanted physiological effects. To overcome onset responses-associated with kilohertz high frequency stimulation several actions have been attempted, as the alteration in current waveforms and electrode geometry or even the combination of different electrodes and types of currents(Patel et al. 2018; Peña et al. 2020). For instance, Sacramento et al.(Sacramento et al. 2018) described that $50 \mathrm{kHz}, 2 \mathrm{~mA}$ applied via cuff electrodes bilaterally in rectangular pulses to the carotid sinus nerve, in rats, did not evoke a transient increase in the activity of this nerve, an observation of clinical

(c) The Author(s). 2021 Open Access This article is licensed under a Creative Commons Attribution 4.0 International License, which permits use, sharing, adaptation, distribution and reproduction in any medium or format, as long as you give appropriate credit to the original author(s) and the source, provide a link to the Creative Commons licence, and indicate if changes were made. The images or other third party material in this article are included in the article's Creative Commons licence, unless indicated otherwise in a credit line to the material. If material is not included in the article's Creative Commons licence and your intended use is not permitted by statutory regulation or exceeds the permitted use, you will need to obtain permission directly from the copyright holder. To view a copy of this licence, visit http://creativecommons.org/licenses/by/4.0/. 
importance for bioelectronics modulation to treat metabolic diseases.

Another shortcoming of kilohertz high frequency stimulation usage and its applicability to the clinics is the energy demand and the hardware needed to supply continuous kilohertz frequencies and high amplitudes to achieve nerve conduction block, particularly when chronic continuous nerve blocking is required to reverse a pathological condition.

Recently, a new modality to achieve nerve conduction block with the potential to mitigate some of the shortcomings related with high frequency blocking and therefore with high potential for clinical use has been described (Muzquiz et al. 2021). Low frequency alternating current waveform $(1 \mathrm{~Hz})$ at the cervical vagus, reversibly blocks in $80 \%$ the bradycardic activity elicited by vagal stimulation in rats, without the presence of onset response and with no apparent injury to the nerve (Mintch et al. 2019). But most importantly, in this edition of "Bioelectronic Medicine" Muzquiz et al. ${ }^{16}$ (2021) demonstrates the efficacy and reversibility of low frequency conduction block on larger caliber myelinated vagal afferent fibers in the swine. The authors tested $1 \mathrm{~Hz}$ sinusoidal current waveform delivered through a bipolar nerve cuff electrode, placed unilaterally to the left cervical vagus nerve, on the ability of nerve to evoke compound action potentials and to produce changes in breathing rate mediated by the Hering-Breuer reflex in anaesthetized swines. They found that cervical vagus nerve low frequency block at current levels of $1.1 \pm 0.3$ $\mathrm{mAp}$ (current to peak), which were within the water window of the working electrode, were able to decrease in $87 \%$ the vagal stimulated reduction in breathing rate through the Hering-Breuer reflex, effects immediately reversed upon unblocking of the nerve, and without any onset response and nerve damage ${ }^{16}$ (Muzquiz et al. 2021). Moreover, they found while monitoring vagus nerve activity that cervical vagus low frequency blocking slow down and reduced the amplitude of components of the compound nerve action potentials, being these changes correlated with the effectiveness of low frequency blocking. Reversible nerve blockade with low frequency alternate current rises as an appealing alternative to high frequency block due to its rapid reversibility, the absence of onset response and its low-threshold characteristics. Nevertheless, further studies are needed to completely elucidate the mechanisms behind nerve block with low frequency alternative current block and to elucidate if this modality might has differential effects on myelinated and unmyelinated fibers. Moreover, of particular importance is understanding if low frequency alternating current block is effective in producing nerve block in other nerves apart from the vagus and in other large species as well as to prove its efficacy and reversibility for long-term use. These clarifications will allow moving low frequency alternative currents usage to promote nerve conduction block closer to the clinics.

\section{Acknowledgements}

Non-applicable.

\section{Author contribution}

SVC wrote entirely the manuscript and reviewed it accordingly.

Funding

Non-applicable.

Availability of data and materials

Non-applicable.

\section{Declarations}

Ethics approval and consent to participate

Non-applicable.

Consent for publication

Non-applicable.

\section{Competing interests}

The author has received in the past funding from Galvani Bioelectronics.

Received: 29 June 2021 Accepted: 7 July 2021

Published online: 26 July 2021

\section{References}

Patel YA, Butera RJ. Challenges associated with nerve conduction block using kilohertz electrical stimulation. J Neural Eng. 2018;15(3):031002. doi:https:// doi.org/10.1088/1741-2552/aaadc0.

Apovian CM, Shah SN, Wolfe BM, Ikramuddin S, Miller CJ, Tweden KS, Billington CJ, Shikora SA. Two-year outcomes of vagal nerve blocking (vBloc) for the treatment of obesity in the ReCharge trial Obes. Surg. 2017;27:169-76.

Sarr MG, Billington CJ, Brancatisano R, Brancatisano A, Toouli J, Kow L, Nguyen NT, Blackstone R, Maher JW, Shikora S, Reeds DN, Eagon JC, Wolfe BM, O'Rourke RW, Fujioka K, Takata M, Swain JM, Morton JM, Ikramuddin S, Schweitzer M. ... The EMPOWER study: randomized, prospective, doubleblind, multicenter trial of vagal blockade to induce weight loss in morbid obesity. Obes Surg. 2012;22:1771-82.

Sacramento JF, Chew DJ, Melo BF, Donegá M, Dopson W, Guarino MP, Robinson A, Prieto-Lloret J, Patel S, Holinski BJ, Ramnarain N, Pikov V, Famm K, Conde SV. Bioelectronic modulation of carotid sinus nerve activity in the rat: a potential therapeutic approach for type 2 diabetes. Diabetologia. 2018;61:700-10.

Boger AS, Bhadra N, Gustafson KJ. Bladder voiding by combined high frequency electrical pudendal nerve block and sacral root stimulation. Neurourol Urodyn. 2008;27:435-9.

Boger AS, Bhadra N, Gustafson KJ. High frequency sacral root nerve block allows bladder voiding. Neurourol Urodyn. 2012;31:677-82.

Taylor RS, Bentley A, Campbell B, Murphy K. High-frequency 10 kHz Spinal Cord Stimulation for Chronic Back and Leg Pain: Cost-consequence and Costeffectiveness Analyses. Clin J Pain. 2020;36:852-61. doi:https://doi.org/10.1 097/AJP.0000000000000866.

Youn Y, Smith H, Morris B, Argoff C, Pilitsis JG. The Effect of High-Frequency Stimulation on Sensory Thresholds in Chronic Pain Patients. Stereotact Funct Neurosurg. 2015;93:355-9. doi:https://doi.org/10.1159/000438998.

Kilgore K, Bhadra N. Nerve conduction block utilizing high-frequency alternating current. Medical Biological Engineering Computing. 2004;42:394-406.

Fjordbakk $C T$, Miranda JA, Sokal D, et al. Feasibility of kilohertz frequency alternating current neuromodulation of carotid sinus nerve activity in the pig. Sci Rep. 2019;9:18136. https://doi.org/10.1038/s41598-019-53566-8.

Ling D, Luo J, Wang M, Cao X, Chen X, Fang K, Yu B. Kilohertz high-frequency alternating current blocks nerve conduction without causing nerve damage in rats. Ann Transl Med. 2019;7(22):661. doi:https://doi.org/10.21037/atm.2019.10.36.

Bhadra N, Kilgore KL. High-frequency electrical conduction block of mammalian peripheral motor nerve. Muscle Nerve. 2005:32:782.

Peña E, Pelot NA, Grill WM. Quantitative comparisons of block thresholds and onset responses for charge-balanced kilohertz frequency waveforms. J Neural Eng. 2020;17:046048. doi:https://doi.org/10.1088/1741-2552/abadb5. 
Mintch LM, Muzquiz I, Horn MR, Carr M, Schild JH, Yoshida K. Reversible conduction block in peripheral mammalian nerve using low frequency alternating current. In: 2019 9th International IEEE/EMBS Conference on Neural Engineering (NER). IEEE. 2019. pp. 823-4.

Muzquiz Ml, Richardson L, Vetter C, Smolik M, Alhawwash A, Goodwill A, Bashirullah R, Carr M, Yoshida K. In-vivo Application of Low Frequency Alternating Currents on Porcine Cervical Vagus Nerve Evokes Reversible Nerve Conduction Block. Bioelectr Med. 2021;7:9. https://doi.org/10.1186/ s42234-021-00072-w.

\section{Publisher's Note}

Springer Nature remains neutral with regard to jurisdictional claims in published maps and institutional affiliations.

Ready to submit your research? Choose BMC and benefit from:

- fast, convenient online submission

- thorough peer review by experienced researchers in your field

- rapid publication on acceptance

- support for research data, including large and complex data types

- gold Open Access which fosters wider collaboration and increased citations

- maximum visibility for your research: over $100 \mathrm{M}$ website views per year

At $B M C$, research is always in progress.

Learn more biomedcentral.com/submissions 